Chirurgia (2020) 115: 681-689

No. 5, September - October

Copyright@ Celsius

http://dx.doi.org/10.21614/chirurgia.115.5.681

\title{
Anal Metastasis from Lung Cancer: Report of a Case and Systematic Review of the Literature
}

\author{
Ovidiu D. Bardac' ${ }^{1}$ Adina-Brîndușa Baciu" lancu S Bogdan-Duică ${ }^{3}$ \\ ${ }^{1}$ First Surgical Clinic, Sibiu Emergency Clinical County Hospital, University "Lucian Blaga" from Sibiu, Romania \\ 2Department of Bio-Medical Anthropology, Institute of Anthropology "Francisc I. Rainer" of the Romanian Academy, \\ Bucharest, Romania \\ ${ }^{3}$ Department of Pathology, Sibiu Emergency Clinical County Hospital, University “Lucian Blaga” from Sibiu, Romania
}

*Corresponding author: Adina-Brîndusa Baciu, MD Department of Bio-Medical Anthropology Institute of Anthropology "Francisc I.

Rainer" of the Romanian Academy

Bucharest, Romania

E-mail: adinabbaciu@yahoo.com

Abbreviations:

CT - computed tomography;

CK7 - Cytokeratin 7;

CK20 - Cytokeratin 20;

HMB45 - Melanosom:

HE, 20X - hematoxylin-eosin coloration, 20X lens;

SCLC - small cell lung cancer;

NSCLC: non-small cell lung cancer.

Received: 22.07 .2020

Accepted: 25.09 .2020

\section{Rezumat}

Metastază anală a unui cancer pulmonar: prezentare de caz și revizuirea sistematică a literaturii

Introducere: $\mathrm{Cu}$ două milioane de cazuri noi înregistrate anual la nivel mondial, cancerul pulmonar este cea mai frecventă formă de cancer. În România cancerele cu cea mai mare incidență sunt cancerul pulmonar la bărbați şi cancerul mamar la femei. Mortalitatea prin cancer urmează acelaşi tipar. Peste 50\% dintre pacienții cu cancer pulmonar prezintă metastaze la distanță în momentul diagnosticării bolii. Cancerul pulmonar metastazează cel mai adesea în creier, oase, ficat şi glandele suprarenale. Metastazele anale în cancerul pulmonar sunt extrem de rare. Conform studiului nostru au fost raportate doar 12 cazuri până în prezent.

Metode:Prezentare de caz şi revizuire sistematică a literaturii. Am efectuat o căutare sistematică a literaturii de specialitate în baza de date PubMed utilizând următorii termeni: „metastaze în cancerul pulmonar” şi ,,anal” sau ,,anus” sau ,,perianal”. Căutarea s-a efectuat de la începutul bazei de date şi până în prezent. Limba de publicare a articolelor nu a reprezentat un criteriu de excludere. Rezultate: Prezentăm cazul unei paciente cunoscută cu adenocarcinom pulmonar avansat care ni s-a adresat pentru o tumoră anală dureroasă, sângerândă şi ulcerată. Tumora a fost excizată în anestezie rahidiană cu închiderea per primam a plăgii operatorii. Examenul anatomopatologic şi imunohistochimic al piesei extirpate a pus în evidență o metastază de adenocarcinom 
pulmonar. Au fost identificate şi studiate 12 articole din literatura de specialitate, conținând 12 prezentări de caz. Raportul bărbați /femei a fost de 3/1. Vârsta medie a fost de 62,16 ani. Doar unul din cazuri avea o tumoră pulmonară cu celule mici. Celelalte 11 cazuri, de tip non-microcelular, au fost: 4 adenocarcinoame, 4 carcinoame cu celule scuamoase , 2 carcinoame nediferențiate şi un carcinom mucoepidermoid. Metastazele anale au fost sincrone în patru cazuri şi metacrone în restul de opt cazuri. Incepând cu anul 2006 un rol important în diagnosticul acestor metastaze joacă imunohistochimia.

Concluzii: Pacienta noastră s-a prezentat cu o metastază anală de adenocarcinom pulmonar care mima o complicație a bolii hemoroidale. Datorită rarității lor, metastazele anale pot fi cu uşurință diagnosticate greşit. Din acest motiv, este recomandabil ca în diagnosticul diferențial al leziunilor ano-perianale ale pacienților cu cancere pulmonare avansate să fie luată în calcul şi posibilitatea existenței unor metastaze. Echipele medicale implicate în tratarea acestor pacienți trebuie să cunoască această eventualitate patologică. Imunohistochimia joacă un rol deosebit de important în stabilirea diagnosticului tumorilor anale şi perianale la pacienții cu neoplasm pulmonar.

Cuvinte cheie: cancer pulmonar non-microcelular, adenocarcinom pulmonar, metastază anală, chirurgie

\section{Abstract}

Background:Lung cancer is the most frequent cancer, accounting for over 2 million new cases per year worldwide. In Romania, the cancers with the highest incidence are lung cancer for men and breast cancer for women. Cancer-related deaths follow the same pattern. More than $50 \%$ of the patients with lung cancers have distant metastases at the time of diagnosis. Metastases from lung cancer occur mainly in the brain, bones, liver, and adrenals. Anal metastases from primary lung cancer are extremely uncommon. As far as we know there are only 12 cases reported in the literature until now.

Case report: Case report and systematic review. We performed a systematic literature search in PubMed using the following MeSH terms: "lung cancer metastasis" AND "anal" OR "anus" OR "perianal". The search was conducted from the beginning of the database onwards. No language exclusion criteria were used. We report the case of a patient with advanced lung adenocarcinoma presenting with a painful, ulcerated and bleeding anal tumor. The anal tumor was excised with primary wound closure in spinal anesthesia. The pathology report and the immunohistochemistry of the specimen revealed metastasis of the lung adenocarcinoma. The review included 12 papers reporting 12 cases. The male/female ratio was 3/1. The average age was 62,16 years. Among these 12 patients, one had a SCLC. From the remaining 11 cases with NSCLC, 4 were adenocarcinomas, 4 squamous cell carcinomas, two anaplastic carcinomas and one mucoepidermoid carcinoma. The anal metastases were synchronous in 4 cases and metachronous in the rest of 8 cases. Since 2006 immuno-histochemistry plays an important role in the diagnosis of these metastases.

Conclusion: Our patient presented an anal metastasis of a lung adenocarcinoma that was masquerading as a complicated hemorrhoidal disease. Because anal masses can be easily misdiagnosed, patients with lung cancers and anal or perianal complaints should be evaluated for metastatic disease. Medical teams that are managing such cases must be aware of this rare but possible situation. Immunohistochemistry plays an important role in establishing the diagnosis for the anal or perianal tumours in patients with lung cancer.

Key words: non-small cell lung cancer, lung adenocarcinoma, anal metastasis, surgery 


\section{Introduction}

Today, cancer is one of the top health threats worldwide. The lifetime risk of developing cancer depends on many factors, including age, race, sex, genetics, and exposure to risk factors (1). According to GLOBOCAN 2018 data, lung cancer is the most frequent cancer for the global population, accounting for 11,6 $\%$ from all new cancer cases, corresponding to over 2 million cases per year worldwide. The leading cause of cancer-related deaths, for both sexes combined, is represented by lung cancer with $18,4 \%$ from all cancer deaths, corresponding to about 1,8 million deaths per year worldwide. GLOBOCAN 2018 data reveal that in Romania the most common type of cancer is lung cancer for men and breast cancer for women while the most common type of cancer mortality follows the same pattern (2).

More than $50 \%$ of the patients with lung cancers have distal metastasis at the time of diagnosis (3). Through early systemic tumor spreading, metastases occur mainly in the lymph nodes, brain, bones, liver, and adrenals $(3,4)$. Metastases seldom occur in uncommon places like skin, pancreas, spleen and gastrointestinal tract (4). Anal and perianal metastases from a lung carcinoma are extremely uncommon (4-6). There are only a few cases reported in the literature until now.

This article aims to present a patient with advanced lung adenocarcinoma that developed an anal metastasis mimicking a complicated hemorrhoidal disease.

\section{Case Report}

We present the case of a 69 years old woman, former heavy smoker. She was admitted to our surgical clinic in March 2018, for pains in the anal region accompanied by rectal bleeding. The symptoms occurred several weeks before and were interpreted by the patient as a consequence of the recent obstipation that occurred after a neurosurgical procedure she underwent in January that year. The patient also reported that she was diagnosed with lung cancer.
A lot of morbid conditions were mentioned in her medical record: a laparoscopic cholecystectomy performed several years before, a peripheral arterial occlusive disease stage IV Fontaine with a right common iliac artery angioplasty with stent insertion and associated right femoropopliteal artery bypass in 2015, arterial hypertension stage III and coronary artery disease.

We could find out the following medical history. On the $16^{\text {th }}$ of December 2016, a thoracoabdominal computed tomography revealed two pathological conditions: an iodophilic spiked tissue mass of $3,5 / 4 \mathrm{~cm}$, located inferiorly and posteriorly in the left upper lobe of the lung, extending to the interlobar fissure and the hilum, associated with enlargement of the paratracheal and hilar lymph nodes up to 1,3 $\mathrm{cm}$; a left adrenal tissue mass of $4,3 / 6 \mathrm{~cm}$ with retroperitoneal paraaortic lymph node enlargement up to $1,6 \mathrm{~cm}$. The $\mathrm{CT}^{-}$scan result was highly suggestive for a primary lung tumor with left adrenal metastasis. The patient was further referred to the urology department where left laparoscopic adrenalectomy was performed on the $21^{\text {st }}$ of December 2016. The histopathology revealed multiple metastases from a lung adenocarcinoma in the parenchyma of the left adrenal gland and the surrounding fat tissue. The postoperative course was uneventful. After the postoperative recovery, the patient went to another medical center to perform further investigations for the lung tumor. The diagnosis of lung adenocarcinoma stage IV: T2, N1, M1 was demonstrated and the indication for palliative chemotherapy was established. During the next months, the patient underwent 4 cycles of chemotherapy starting with Bevacizumab and continuing with the association of Carboplatin and Pemetrexed. In March 2017 chemotherapy was stopped because of poor results and bad tolerance. In September 2017 a new CT scan was performed that revealed a recurrence of the metastases in the left adrenal gland with the invasion of the left diaphragmatic crus and a small mass at the upper pole of the spleen. The lung tumor was relatively constant in shape and dimensions.

In January 2018 the patient was admitted 
to the neurosurgical department for intracranial hypertension syndrome and mixed aphasia. A cerebral magnetic imaging resonance reveals a left frontal lobe intracerebral mass of $39 \mathrm{~mm}$ width interpreted as a subacute hematoma. On the $10^{\text {th }}$ of January, the patient underwent surgical treatment to remove the tumor from the left frontal lobe. The postoperative course was uneventful with the improvement of the neurological status. Histology revealed a metastasis from the lung tumor.

A new CT scan, performed in March 2018 showed a global worsening of the disease with the enlargement of both the lung tumor and the left adrenal recurrence. Furthermore, the number of splenic metastases increased to three and an image suggestive for metastasis in the body of the $8^{\text {th }}$ thoracic vertebra occurred.

At admission, the local clinical exam performed in lithotomy position revealed a moderately painful, $5 / 2 \mathrm{~cm}$ anal tumor at 7 o'clock, with both skin and mucosal ulceration (Fig. 1). The digital rectal exam showed a normotonic internal anal sphincter and no pathological findings above the dentate line. The development of the tumor seemed to be more towards the periphery and did not involve the internal anal sphincter.

The next day, on the $7^{\text {th }}$ of March 2018 we underwent in spinal anesthesia the tumor excision with primary wound closure (Fig. 2 and 3). The postoperative course was uneventful. The patient was discharged on the second postoperative day.

A week after the discharge the patient presented herself again at the hospital for rectal bleeding. The clinical examination revealed a freshly occurred wound dehiscence. The stitches were removed and the wound was left open for secondary healing. After a week the patient was discharged in good clinical condition, without pain, bleeding or inflammation. The postoperative wound was partially healed and the patient presented no fecal incontinence.

The pathology report (no. 6565/6569) showed: nodular tissue infiltration with cells

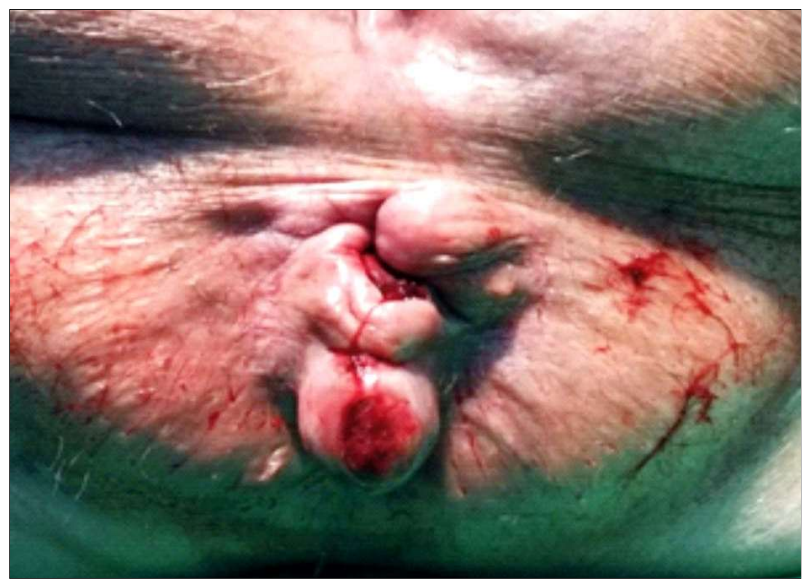

Figure 1. Ulcerated anal tumour at 7 o'clock clock lithotomy position

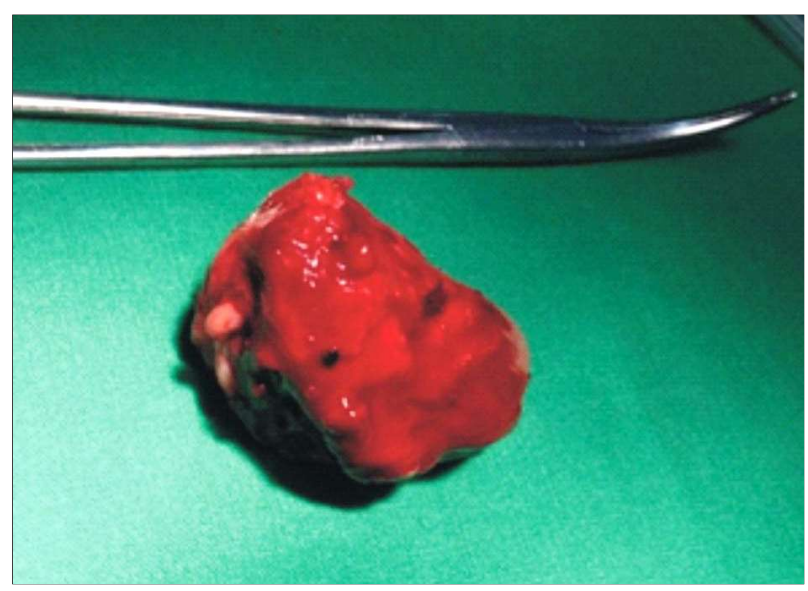

Figure 2. Operative specimen

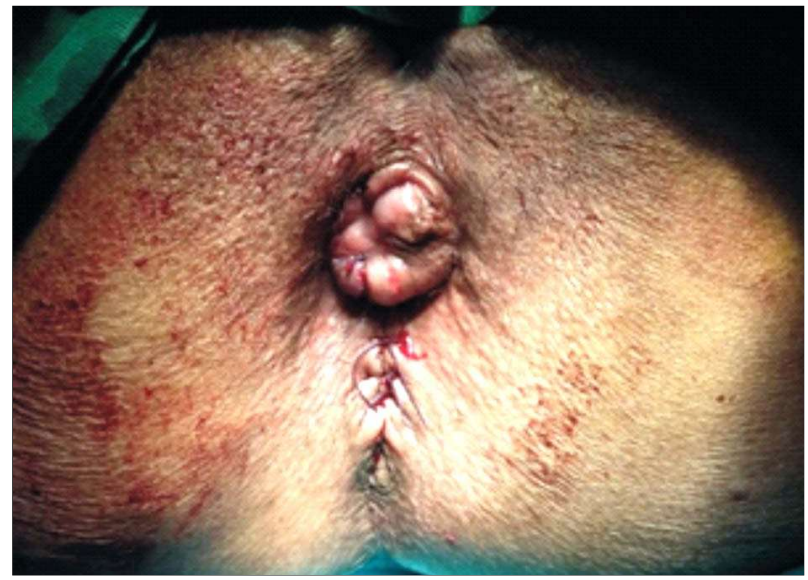

Figure 3. Postoperative aspect

with moderate pleomorphism, more eosinophilic cytoplasm, vacuolization and isolated formation 


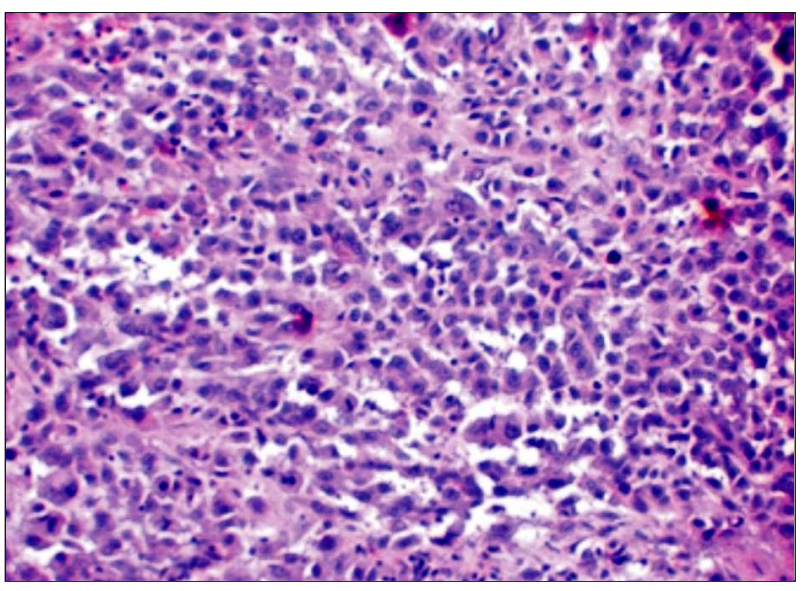

Figure 4. HE, $20 \mathrm{X}$

of positive alcian mucin; numerous mitosis; central necrosis and hemorrhage; moderate inflammatory reaction around (Fig. \). The lesion is completely excised. The immunophenotyping revealed: Cytokeratin 7 (CK7) positive (Fig. 5), Cytokeratin 20 (CK20) negative, Melanosom (HMB45) - negative, Ki67-40\%. Conclusions: metastasis of adenocarcinoma.

The case study was done by following the ethical norms of scientific research and the principles of anonymity and confidentiality.

\section{Systematic Review of the Literature}

We performed a systematic literature search in PubMed using the following MeSH terms: "lung cancer metastasis" AND "anal" OR "anus" OR "perianal". The search was conducted from the beginning of the database till present. No language exclusion criteria were used. The search revealed 226 papers. From the 226 results only 12 papers were selected. The others were excluded being off topic. A second "reference in reference" search was performed and this revealed another two significant papers $(9,17)$. All the 14 papers were case reports, except one that included also a literature review. This was the paper of Al-Tarakji at all. published in 2016 (18). During the process of final selection another two papers were excluded because the metastases were located in the gluteal regions (but-

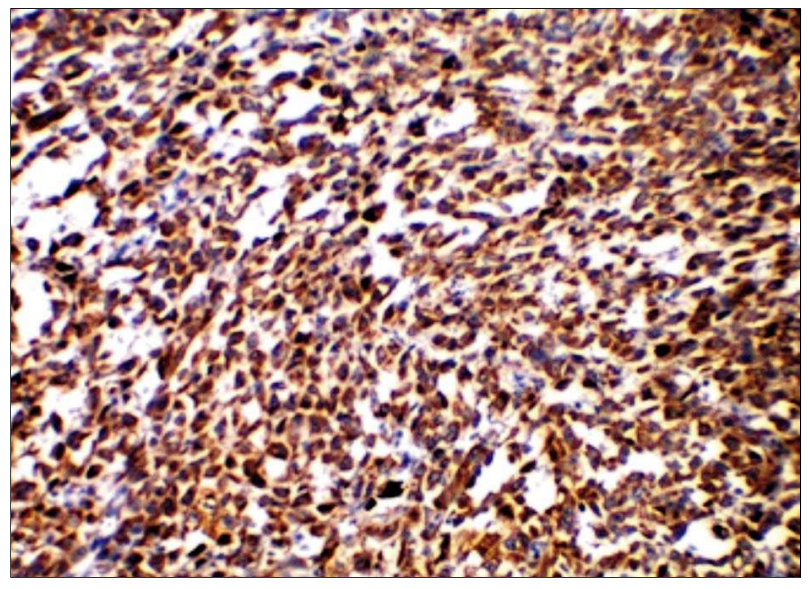

Figure 5. CK 7 positive, 20X

tocks), separate from anus or perianal region. The first of these two cases was reported by Srikanth in 1999 (9) and the second by Tek in 2007 (10). The remaining 12 papers, reporting 12 cases, were accesed as follows: 10 in full text , 1 abstract (6) and title in 1 case (12). We kept this last paper because the work was cited as relevant by other authors. All important data, like gender, age, pathology, location and therapy of primary tumour, metastases localization and therapy, immunohistochemical confirmation were registered in a table (Table 1).

\section{Results}

Thorough literature research revealed only 12 reports of primary lung cancers that developed anal or perianal metastases (Table 1). The male/female ratio was $3 / 1$, represented by 9 men and 3 women and the average age was 62.16 years. Among these 12 patients, only one had a SCLC, women, reported by Guerrera in 2014 (11). From the remaining 11 cases with NSCLC (4-6,12-19), 4 were adenocarcinomas (14, 15, 18, 19), 4 Squamous Cell Carcinomas (5, 12, 13, 17), 1 Mucoepidermoid Carcinoma (6) and two anaplastic carcinomas $(4,16)$. The surgical therapy of the primary tumour was attempted only in two cases: a right middle and lower lobectomy combined with left atrial wall resection (13) and a left pneumonectomy (19). In both cases the anal metastases devel- 
Table 1. Primary lung cancers with anal metastases, reported cases

\begin{tabular}{|c|c|c|c|c|c|c|c|c|}
\hline No. Year & $\begin{array}{c}\text { First } \\
\text { Author }\end{array}$ & Gender & Age & Pathology & Primary tumour & Metastases & $\mathrm{IHC}^{*}$ & $\begin{array}{l}\text { Treatment and outcome } \\
\text { of anal metastases }\end{array}$ \\
\hline 11968 & Ger (5) & M & 49 & $\begin{array}{l}\text { Well differentiated } \\
\text { Squamous-Cell } \\
\text { Carcinoma }\end{array}$ & $\begin{array}{l}\text { Left superior lobe, } \\
\text { no specific treatment }\end{array}$ & $\begin{array}{l}\text { Anal canal, } \\
\text { myocardium, syn** }\end{array}$ & no & $\begin{array}{l}\text { Abdominoperineal } \\
\text { resection, death in } \\
\text { the } 3^{\text {rd }} \text { postop day }\end{array}$ \\
\hline 21975 & $\begin{array}{l}\text { Kanhouwa } \\
\text { (4) }\end{array}$ & M & 45 & $\begin{array}{l}\text { Anaplastic } \\
\text { Large-Cell } \\
\text { Carcinoma }\end{array}$ & $\begin{array}{l}\text { Right upper lobe } \\
\text { Radiotherapy and } \\
\text { chemotherapy }\end{array}$ & $\begin{array}{l}\text { Marginal anus, ulcerated, } \\
\text { met *** ( } 2 \text { months) } \\
\text { Inguinal lymph nodes, } \\
\text { skin of the lower abdomen }\end{array}$ & no & $\begin{array}{l}\text { Biopsy, radiotherapy } \\
\text { and chemotherapy } \\
\text { Survives } 6 \text { months }\end{array}$ \\
\hline 31988 & Uemura (6) & M & 78 & $\begin{array}{l}\text { Mucoepidermoid } \\
\text { Carcinoma }\end{array}$ & No data available & Perianal skin and other, syn & no & $\begin{array}{l}\text { Radiotherapy, dies in } \\
\text { less than one year } \\
\text { because of great hemorrhage } \\
\text { from the perianal mass }\end{array}$ \\
\hline $4 \quad 1994$ & $\begin{array}{l}\text { Kawahara } \\
\text { (13) }\end{array}$ & M & 75 & $\begin{array}{l}\text { Squamous Cell } \\
\text { Carcinoma }\end{array}$ & $\begin{array}{l}\text { Right lung; right middle } \\
\text { and lower lobectomy } \\
\text { combined with left atrial } \\
\text { wall resection }\end{array}$ & $\begin{array}{l}\text { Prolapsed anal canal polyp, } \\
3 \text { months, met }\end{array}$ & no & $\begin{array}{l}\text { Transanal polypectomy, } 9 \\
\text { months without recurrence }\end{array}$ \\
\hline 52006 & $\begin{array}{l}\text { Wisniewski } \\
(14)\end{array}$ & $\mathrm{M}$ & 53 & Adenocarcinoma & Could not be identified & $\begin{array}{l}\text { Anal abscess, } 11 \text { months, met } \\
\text { Brain and mediastinal lymph nodes }\end{array}$ & yes & $\begin{array}{l}\text { Incision, drainage; dies in } 1 \\
\text { month }\end{array}$ \\
\hline 62010 & Okutur (12) & $\mathrm{M}$ & 64 & $\begin{array}{l}\text { Squamous Cell } \\
\text { Carcinoma }\end{array}$ & No data available & $\begin{array}{l}\text { Anal canal, polyp, met } \\
\text { and pleural }\end{array}$ & $\begin{array}{l}\text { No } \\
\text { data }\end{array}$ & Excision and Radiotherapy \\
\hline $7 \quad 2012$ & Camus (15) & $\mathrm{F}$ & 53 & $\begin{array}{l}\text { Moderately } \\
\text { differentiated } \\
\text { Adenocarcinoma, } \\
\text { with clear cells }\end{array}$ & $\begin{array}{l}\text { Left lung, palliative } \\
\text { chemotherapy }\end{array}$ & $\begin{array}{l}\text { non-healing perianal ulceration, } \\
\text { Liver, subcutaneous, lymph nodes }\end{array}$ & yes & $\begin{array}{l}\text { Biopsy, radio and } \\
\text { chemotherapy }\end{array}$ \\
\hline $8 \quad 2014$ & Imai (16) & $\mathrm{F}$ & 36 & $\begin{array}{l}\text { NSCLC, poorly } \\
\text { differentiated } \\
\text { carcinoma }\end{array}$ & $\begin{array}{l}\text { left superior sulcus } \\
\text { tumor, palliative } \\
\text { radiotherapy }\end{array}$ & $\begin{array}{l}\text { Haemorrhoid, painless perianal } \\
\text { mass, met, } \\
\text { Subcutaneous and multiple brain } \\
\text { metastases }\end{array}$ & yes & Excision \\
\hline 92014 & Guerra (11) & $\mathrm{F}$ & 75 & SCLC & $\begin{array}{l}\text { Not specified, } \\
\text { chemotherapy }\end{array}$ & $\begin{array}{l}\text { Perianal abscess, } 1 \text { month later } \\
\text { under Chemotherapy, met, and } \\
\text { iliac bone metastasis }\end{array}$ & yes & Biopsy and chemotherapy \\
\hline 102014 & Kılıç (17) & M & 73 & $\begin{array}{l}\text { Squamous Cell } \\
\text { Carcinoma }\end{array}$ & $\begin{array}{l}\text { posterior segment of } \\
\text { the upper lobe of the } \\
\text { right lung }\end{array}$ & $\begin{array}{l}\text { Perianal abscess and right adrenal, } \\
\text { syn }\end{array}$ & no & $\begin{array}{l}\text { Incision, biopsy, referred for } \\
\text { adjuvant therapy }\end{array}$ \\
\hline 112016 & $\begin{array}{l}\text { Al-Tarakji } \\
(18)\end{array}$ & M & 75 & $\begin{array}{l}\text { NSCLC, } \\
\text { Adenocarcinoma }\end{array}$ & $\begin{array}{l}\text { Left-apical segment } \\
\text { (Pancoast), palliative } \\
\text { RT and Chemotherapy }\end{array}$ & $\begin{array}{l}\text { Anal ulcerated mass, met } \\
\text { (7 months) } \\
\text { Liver, adrenal, chest wall }\end{array}$ & yes & Biopsy, dies in 1 month \\
\hline 122016 & $\begin{array}{l}\text { Dhandapani } \\
\text { (19) }\end{array}$ & M & 70 & $\begin{array}{l}\text { NSCLC, } \\
\text { Adenocarcinoma }\end{array}$ & $\begin{array}{l}\text { Left lower lobe, } \\
\text { pneumonectomy, } \\
\text { no chemotherapy }\end{array}$ & $\begin{array}{l}\text { Perianal abscess } 3 \text { months later, } \\
\text { met }\end{array}$ & yes & $\begin{array}{l}\text { Incision, drainage, biopsy, } \\
\text { dies in } 2 \text { weeks }\end{array}$ \\
\hline 132018 & Our case & $\mathrm{F}$ & 69 & Adenocarcinoma & $\begin{array}{l}\text { Left upper lobe, } \\
\text { palliative chemotherapy }\end{array}$ & $\begin{array}{l}\text { Anus (Haemorrhoidal thrombosis), } \\
\text { met, } 15 \text { months } \\
\text { Also adrenal, spleen, brain, spine }\end{array}$ & yes & Excision \\
\hline
\end{tabular}

oped in three months after surgery. In 8 cases was attempted only palliative radiotherapy and chemotherapy. For two cases the data are missing $(6,12)$. The anal metastases were synchronous in 4 cases and metachronous in the rest of 8 cases. For the last 8 cases the interval of occurrence varied between 1 and 11 months. Since 2006 almost all the cases were immunohistochemically confirmed. This started with the work of Wisiniewski et al. (14). The treatment of anal metastases consisted of: biopsy and radiotherapy in 5 cases, incision and biopsy in 3 cases (for abscess like mases), excisions in three cases and an abdominoperineal resection.

\section{Discussion}

Lung cancer is categorized into two main histological groups: small cell lung carcinoma 
(SCLC, $15 \%$ of all lung cancers) and non-small cell lung carcinoma (NSCLC, $85 \%$ of all lung cancers) $(7,8)$. The main types of NSCLCs are adenocarcinoma, squamous cell carcinoma, and large cell carcinoma. Adenocarcinoma is the most common type of lung cancer, accounting for more than $40 \%$ of lung cancers and more than $50 \%$ of the NSCLC types (7). The incidence of adenocarcinoma has risen steadily over the past few decades.

Not only the pathologic type but also the stage of the disease and the general status of the patient are determinant factors for choosing the right therapy protocol (8). Curative therapy of lung cancer is strongly limited by the great number of patients diagnosed in advanced stages. More than $50 \%$ of lung cancer patients have distant metastases at the time of diagnosis (3). Anyway the perianal region is a very uncommon metastasis site. The literature research revealed 12 cases with anal or perianal metastases secondary to lung cancer. Our patient is a 69 years old woman, with a lung adenocarcinoma that subsequently developed an anal metastasis.

Including our case, the majority of anal metastases occurred in NSCLC (12 cases from 13). The reason for this fact could be the higher proportion of NSCLC among lung cancers (8085\%) and the higher aggressiveness of the SCLC that leads to much shorter survival periods.

The 12 reported cases of anal metastases from lung cancer embrace the following clinical patterns: 4 perianal abcess like lesions, 4 marginal anal masses (with or without ulcerations), 3 tumours of the anal canal (two polypoid), and 2 perianal nonhealing skin ulcerations. Remarcable is that all three metastasis located in the anal canal originate from a squamous cell carcinoma of the lung. These types of lesions are suitable for local excision when early diagnosed. All the other clinical forms of anal metastases suggest different stages in the evolution of the tumours, from nodular lesions, to necrosis, abscess formation and finally the development of ulcerations. In these cases, the early diagnosis in the nodular stage of the tumour is very important for the surgical treatment. The histological pattern of these tumours is variable, all types of NSCLC being encountered.

In our case, the anal metastasis being early diagnosed, could be operated with good results. Complete local excision of the nodular lesion with mucosal ulceration located at the anal verge was performed (Figs. 2 and 3). The pathology report demonstrated the removal of the entire tumor. In our opinion, this should be the attitude whenever is possible. Good results with local excision were reported also by other authors $(12,13,16)$ even though, two of them were performed for polypoid metastatic tumors. In opposite, invasive surgery like abdominoperineal resection could lead to disastrous results as previously reported (5). Most of the cases reported in the literature were treated by surgical drainage of abscesslike masses associated with biopsy, or biopsy alone with adjuvant radiotherapy $(6,11,14,15$, $17,18,19)$. The results are not so good as in the radical excision because the metastases evolve developing a lot of complications that significantly alter the quality of life for these patients (4). A case of death due to massive bleeding from a reccured perineal metastasis is also reported in the literature (6). Even though the surgical excision will not improve the survival rate, will improve the quality of life for these patients. In large infected, exulcerated anal metastasis, when the surgical resection is not feasible a palliative colostomy should be taken into account.

Most of the reported cases presented also other secondary deposits at the time of the anal metastasis diagnosis. Our patient had adrenal, splenic, cerebral and spinal metastases. Moreover, our patient underwent three surgical procedures, from December 2016 to March 2018, and none of those addressed to the primary tumor but only to the metastases. The diagnosis of lung adenocarcinoma was preceded by the left laparoscopic adrenalectomy.

The anal metastasis was histologically and immunohistochemically documented. The tumor cells were positive for CK7 (Fig. 5) and negative for CK20 revealing an adenocarcinoma of lung origin while adenocarcinomas of colo- 
rectal origin are mostly CK7 negative / CK20 positive (14).

\section{Conclusions}

Anal or perianal metastases in primary lung cancers are very rare. According to our knowledge, our case is the $13^{\text {th }}$ reported in the literature. Our case proves that if the diagnosis of the anal metastasis is early a complete surgical excision is possible and appropriate. The surgical excision is easily feasible in polypoid like metastasis originating from the anal canal or in the nodular stage of the perianal metastasis, before the development of necrosis, abcess and ulceration. The complete surgical excision should be performed whenever it is possible because other treatments, like radiotherapy, can only temporarily alleviate the local situation. The tumor will regrow, will develop cutaneous and mucosal ulcerations, infection, bleeding and eventually anal stenosis. In such cases performing a colostomy could be the right and only option. The surgical excision is only possible when the metastasis is early diagnosed. This is the reason why the medical teams that are managing such cases must be aware of this rare but possible situation.

Including our case, the majority of anal metastases occurred in NSCLC (12 cases from 13). The reason for this fact could be the higher proportion of NSCLC among lung cancers $(80-85 \%)$ and the higher aggressiveness of the SCLC that leads to much shorter survival periods. We noticed a correlation between the histological type of squamous cell carcinoma of the lung cancer and the polypoid metastases, located in the anal canal. This aspect should be further investigated.

As previously mentioned, more than $50 \%$ of lung cancer patients have distant metastases at the time of diagnosis (3). This fact drastically limits the indication of curative therapy. Even though curative treatment is not indicated, the patients with metastatic lung cancer need frequent surgical palliation. Among these situations is the rare case of developing an anal metastasis. A proper diagnosis and management of this situation brings a lot of improvement in the quality of life of these patients.

\section{Conflict of Interest}

The authors declare that they have no conflict of interest concerning this article.

\section{Ethics Approval}

The case study was done by following the ethical norms of scientific research and the principles anonymity a confidentiality.

\section{Authors' Contributions}

Ovidiu D Bardac: concepualization, methodology, investigation, writing - original draft. AdinaBrînduşa Baciu: writing - review \& editing, visualization. Iancu S Bogdan-Duică: methodology, investigation. All authors critically revised the manuscript, approved the final version to be published, and agree to be accountable for all aspects of the work.

\section{References}

1. Lung Cancer Statistics. Available on: https://www.cancerresearchuk.org/health-professional/cancer-statistics/statistics-bycancer-type/lung-cancer.

2. Bray F, Ferlay J, Soerjomataram I, Siegel RL, Torre LA, Jemal A. Global cancer statistics 2018: GLOBOCAN estimates of incidence and mortality worldwide for 36 cancers in 185 countries. CA: A Cancer Journal for Clinicians. 2018; 68(6):394-424.

3. Yang CJ, Hwang JJ, Kang WY, Chong IW, Wang TH, Sheu CC et al. Gastro-intestinal metastasis of primary lung carcinoma: clinical presentations and outcome. Lung Cancer. 2006;54(3): 319-323.

4. Kanhouwa S, Burns W, Matthews M, Chisholm R. Anaplastic carcinoma of the lung with metastasis to the anus: report of a case. Dis Colon Rectum. 1975;18:42-8.

5. Ger R, Reuben J. Squamous-cell carcinoma of the anal canal: a metastatic lesion. Dis Colon Rectum 1968;11:213-219.

6. Uemura Y, Ohtsuki Y, Sonobe H, Nakamura S, Takeuchi T, Fujishita $M$, Miyoshi I. (Perianal skin metastasis in a case of lung cancer). Abstract. GanNoRinsho. 1988;34(8):1054-6.

7. Zugazagoitia J, Enguita AB, Nuñez JA, Iglesias L, Ponce S. The new IASLC/ATS/ERS lung adenocarcinoma classification from a clinical perspective: current concepts and future prospects. J Thorac Dis. 2014;6 (Suppl 5): S526-S536.

8. Huber RM, Tufman A. Lungenkarzinom (Lung cancer). DtschMed Wochenschr. 2014;139(11):545-556.

9. Srikanth B, Sankar N S, Kong K C, Bassily A A. Lessons to be learned: 
a case study approach: metastatic bronchogenic carcinoma presenting as a gluteal abscess. J R Soc Promot Health. 1999;119(4):264-7.

10. Tek I, Iyidir OT, Utkan G, Ceyhan K, Buyukcelik A, Yalcin B, et al. Lung cancer metastasis mimicking gluteal abscess. Southern medical journal. 2007;100(3):334-5.

11. Guerra F, Amore Bonapasta S, Tumbiolo S, Gentile E, Coratti A. Lung cancer metastasis to the external anal sphincter mimicking perianal abscess. International journal of colorectal disease. 2015; 30(4):581-2.

12. Okutur K, Arslan K, Bozkurt M, Barlan M, Oz B, Demir G. Squamous cell carcinoma of the lung with anal canal metastasis. J BUON. 2010;15(1):194.

13. Kawahara K, Akamine S, Takahashi T, Nakamura A, Kusano $\mathrm{H}$, Nakagoe T, Nakazaki T, Ayabe H, Tomita M . Anal metastasis from carcinoma of the lung: report of a case. Surgery today. 1994; 24(12):1101-3.

14. Wisniewski B, Vuong PN, Balaton A, Bauer P, Brugger S, Janzen J. Métastaseanale d'un cancer broncho-pulmonaire. Gastroenterologie clinique et biologique. 2006;30(3):471-2.

15. Camus M, de Parades V, Fléjou JF, Atienza P, Zeitoun JD. Synchronous perianal metastasis of lung adenocarcinoma: report of a case. Clinics and research in hepatology and gastroenterology. 2013;37(6):e143-4.

16. Imai H, Inafuku K, Wakuda $\mathrm{K}$, Ono A, Taira $\mathrm{T}$, Kenmotsu $\mathrm{H}$, et al. Perianal metastasis of non-small cell lung cancer. Internal medicine (Tokyo, Japan). 2014; 53(11):1149-52.

17. Kılıç MÖ, Şen M, Türkan A, Yıldırım Ü, Köktener A. An Unusual Presentation of Lung Cancer Metastasis: Perianal Abscess. J Clin Anal Med. 2014;5(suppl 3):369-71.

18. Al-Tarakji M, Feilchenfeldt J, Haidar A, Szabados L, Abdelaziem S, Sayed $A$, et al. Rare occurrence of metastasis from lung cancer to the anus: case report and review of the literature. World J Surg Oncol. 2016;14(1):157.

19. Dhandapani RG, Anosike C, Ganguly A. Non-small cell lung carcinoma metastasis to the anus. BMJ Case Rep. 2016;2016: bcr2016214653. doi: 10.1136/bcr-2016-214653. 